\title{
Overview of Surrogates to Measure Audit Quality
}

\author{
Fuad Elmahedi Hussein ${ }^{1} \&$ Mustafa MohdHanefah ${ }^{1}$ \\ ${ }^{1}$ Faculty of Economics and Muamalat, UniversitiSains Islam Malaysia, Malaysia \\ Correspondence: Fuad Elmahedi Hussein, Faculty of Economics and Muamalat, UniversitiSains Islam Malaysia \\ (USIM), Malaysia. E-mail: fuadh99@yahoo.com
}

Received: May 23, 2013

Accepted: June 27, 2013

Online Published: August 10, 2013

doi:10.5539/ijbm.v8n17p84

URL: http://dx.doi.org/10.5539/ijbm.v8n17p84

\begin{abstract}
After the collapse of Arthur Andersen in 2002, the auditing profession has faced increasing pressure from external parties to enhance and improve audit quality. These pressures led to a continued need to study the factors that affect audit quality. Until present, there is no agreement among researchers about the definition and factors of audit quality. To date, the issue of how audit quality is measured remains a matter of controversy and disagreement. Previous studies used alternatives to measure audit quality. This paper reviews both the arguments for and against for these studies. Although, the importance of these alternatives and its potential contribution on audit quality have been emphasized, they are not a justification to ignore audit characteristics that could have significant impact on audit quality. This paper contributes to audit literature and represents a brief overview of reviews both the arguments for and against of using audit quality alternatives in previous studies over the past 30 years. Thus it provides a basis for discussing several potentially rich factors for future research on audit quality.
\end{abstract}

Keywords: audit quality, audit firm size, auditor tenure, provision of non-audit services, industry experience, peer review

\section{Introduction}

Until today, there is no agreement among researchers about a specific definition ofaudit quality. Abdel Ghany (2012) finds that currently, there are some audit bodies thatdo not have a generally accepted definition of audit quality nor a universally accepted measuring technique. As summarized by Sutton (1993), the cause for the absence of consensus of a single definition of audit quality is due to the apparent conflicting roles of participants in the audit market. The major audit market participants can be grouped into three categories: (1) external users; (2) the client; and (3) the auditors. There are many definitions, but it could be argued that this concept encapsulates the following two fields: DeAngelo (1981) provides one of the most frequently cited definitions of quality. She noted that the quality of an audit is related to whether an auditor will discover an error in the financial statements and report the error in the audit report. She adds that auditor lacking in auditor independence will be less likely to report a discovered breach, thus reducing audit quality. In contrast, IFAC, (2007) finds that, quality is the most fundamental characteristic of international auditing standards, and quality standards should be capable of consistent interpretation, enforceable, capable of unambiguous translation, and designed to achieve a high quality audit. Practitioners of the audit profession often define audit quality relative to auditors' ability to meet legal and professional requirements (Francis, 2004; Watkins et al., 2004; Broberg, 2007). Several researchers have adopted DeAngelo's definition, such as; (Palmrose, 1988; Epstein \& Geiger, 1994; Willekens \& Simunic, 2007). On the other hand, Kilgore (2007) observes whilst the DeAngelo definition of audit quality has been widely quoted, it has also been criticized as not being broad enough and incomplete, and as a consequence, does not provide a full definition for audit quality. In light of IFAC definition, audit quality can be considered dichotomous. Audit is considered to be of poor quality if an auditor fails to comply with legal and professional requirements; in other words, an audit failure occurs. It is worth mentioning that the professional bodies which oversee the audit profession concerned with this definition based on the link between audit quality and commitment to professional standards are issued it by themselves (Ehlen \& Welker, 1996).

Similarly, there is no agreement among researchers about measurement of audit quality. This view is supported by Reisch (2000) who argues that audit quality is a multi-dimensional potential construct; it is extremely difficult to measure and as a result, the extant literature reflects sundry measures of audit quality. On the same note, Iskandar, et al., (2010) found that, consensus has not been reached on how audit quality should be 
measured. According to the Basel Committee (2008), there is no tool to measure audit quality, but there are recent efforts that appraised how to measure it. To measuring audit quality, researchers have taken one of the following approaches, which are: (1) direct approach, based on assumption that reporting of contract breaches and the probability of discovery will be reflected in features of the audit such as abuses and errors made by auditors; and (2) an indirect approach by looking at correlates of audit quality (Kilgore, 2007). However, the direct approach depends on the application of self-censorship by the auditors themselves, thus direct approach is difficult to reach, because it is difficult to report on contract breaches, abuses and errors made by same auditors. In contrast, the indirect approach measures audit quality from an ex-ante perspective either using surrogates of quality or checking the attributes or factors perceived to be associated with audit quality (Kilgore, 2007). Therefore, majority of previous studies that have attempted to measure audit quality have use indirect approach to measure audit quality, and more specifically, have use surrogates of audit quality since audit market participants are generally unable to observe audit quality directly. For example: Big 4 firm;DeAngelo, 1981; Colbert \& Murray, 1999; Sori et al, 2006; Choi et al., 2010. Auditor tenure; Arel et al., 2005; Jackson et al., 2008; Chi et al., 2009. Non-audit services; Defond et al., 2002; Rasmussen, 2005; Felix et al., 2005. Industry specialization; Hogan \& Jeter,1998; Schauer2002; Reichelt \& Wang,2010; Schauer. Litigation; Palmrose, 1988. Peer reviewer; Hillary \& Lennox 2005; Casterella et al., 2009.

\section{Surrogate Studies of Audit Quality in Previous Studies}

The previous studies have identified a range of audit quality factors significant in assessments of audit quality. The main factors investigated in surrogate studies of audit quality include the following; audit firm size, litigation, auditor tenure, non-audit services, industry experience, and peer review. Each of these factors is discussed in the order below.

\subsection{Audit Firm Size}

Several studies provide evidence supporting impact of the size of the office in audit quality. Davidson (1993) claims that the difficulty in measuring audit quality led numerous researchers to utilization audit firm size as an alternative. Many researchers believe that the greater the firm's size the greater the audit quality will be enhanced (e.g., DeAngelo, 1981; Francis et al., 1999; Sori et al, 2006; Choi, et al, 2010). DeAngelo (1981) assumed that big audit firms have top ability to specialize and innovate by technical and technology, thereby increasing the likelihood of breach discovery in the accounting system, and the discovery of errors and manipulation. She also of the view that big audit firms are more independent from their customers, thereby increasing the likelihood of identified breach reporting. DeAngelo used these hypothesizes that larger firms provide usually has higher quality audits. According to Francis et al., (1999) assert that the international Big 6 (they became the Big 4 in 2002) auditing firms have brand-name reputations and are widely viewed as producing higher quality audits than non-Big 6 firms. Sori et al, (2006) find that, Big audit firms have more talented employees and superior technology, research facilities, and best financial resources to undertake audit process than smaller audit firms. Colbert \& Murray (1999) has observed that big firms possess incentives to deliver high quality audits, and their partner human capital is highly dependent on the firm retaining its reputation. Many studies view the size of big firms as capable of providing higher quality audit process and offer greater credibility to customers' financial statements compared to small audit firms, because they have technical expertise, enjoy best reputations, and have higher brand equity. On the same note, larger audit firms have generally been viewed as being greater independent. That perception is clearly evident in literature relating to audit quality dating back over a span more than three decades. This view has been supported by several researchers (e.g. DeAngelo, 1981; Davidson, 1993; Lennox, 1999; Colbert \& Murray, 1999; Sori et al., 2006; Choi, et al, 2010).

Subsequent studiesdid not supportDeAngelo's results, for example; Wyer et al., (1988) considers the weak test of DeAngelo's theory on the relationship between auditor size and audit quality. Tests of reporting patterns across the tiers and groups found no important association between audit firm size and reports issued by auditors. Theory shows that smaller firms issued a larger proportion of qualified reports, despite this difference is not sufficiently large to indicate an overall relationship between size and reporting patterns but the assumption that, audit firm size and audit quality (as defined by DeAngelo) are related is not supported by the findings of this study (Wyer et al., 1988). Francis (2004) reported that in the aftermath of the collapse of Arthur Andersen in 2002, it has become fashionable to criticize auditing and to question the quality of audit process being performed by auditing firms, especially the Big 4 auditing firms. In addition, there is other evidence showing that the largest auditing firms may not always provide higher quality audits than do small auditing firms (e.g., Tate, 2002; Lam \& Chang, 1994). Imhoff (1988) claims that, the relationship between audit firm size and quality is still called into question until today. After following the collapse of Arthur Andersen in 2002, the 
quality of the Big 4 was thrown under suspicion. Tate (2002) finds that the largest auditing firms may not always provide higher quality audits compared to small auditing firms. He found the Big 5 auditors' report more noncompliance with federal regulations and he finds Big 5 auditors less likely rather than more likely to report significant deficiencies in internal controls. This view is supported by recent studies, e.g. in the context of Malaysia, Carlin et al. (2009) notes that there is little evidence in extant literature supportive of quality differentials between Big 4 firms, except that the collapse of Arthur Anderson certainly undermines this assertion that large auditors are associated with higher audit quality.

There is no doubt that the big audit firms have the ability, potential qualification, qualified auditors, competent elements, use of technical information, and use of sophisticated and effective methods so, the result is high-quality audits and developed audit profession. The big audit firm has an impact on quality, but it cannot measure audit quality alone in isolation from all other factors. So, it is an important factor of audit quality measurement.

\subsection{Litigation}

Palmrose (1988) used auditor litigation as a surrogate for audit quality, he found differences between Big firm and non-Big firms, specifically that Big firm auditors were less likely to be involved as defendants in audit litigation based on the assumption that a higher (lower) quality auditor is involved in less (more) audit litigation. Schwartz (1997) finds that legal systems impacting auditors composed of liability rules and damage measures, and liability rules determine whether an auditor is liable for the damages incurred by plaintiffs /investors while damage measures the amount that the (plaintiffs/investors) can recover from an auditor found liable. The laws and regulations are binding for the auditors (individuals) and audit firms. On the individual level, the auditors are required to have a specific level of education and practical experience. At the same time, these laws and regulations are governing the relationship between audit firm and its employees, organizing the relationship between audit offices with each other, audit firm and its customer, and also organizing the relationship among the audit firm and the community. In 2002, Arthur Andersen was liquidated as a result of negligence and fraud in the performance of their duties and lack of commitment to professional ethics; thus, Palmrose's findings were thrown under suspicion. Besides that, it may be difficult in many cases to reveal the number of cases brought against audit firms since in most cases they are settled out of court and not known to the press. Therefore, it cannot use the litigation as a surrogate for audit quality alone in isolation from all other factors. So, it is an important factor of audit quality measurement.

\subsection{Auditor Tenure}

Auditor tenure has been regarded as a surrogate for audit quality. Some researchers believe the existence of a strong relationship between audit quality and auditor tenure (e.g., Arel et al., 2005; Jackson et al., 2008; Chi et al., 2009). This view has experienced an increasing growth after Sarbanes-Oxley (SOX) Act was issued in 2002, which refers to the mandatory rotationof auditors from five to seven years (SOX, 2002, section 207). However, there is no agreement among researchers about the impact of auditor tenure on audit quality. Some researchers argue that long auditor rotation has a negative impact on audit quality (Geiger \& Raghunandan, 2002; Arel et al., 2005; Chi et al., 2009). The long relationship between the Enron and Andersen firm is a good example along with the intimate relationships between employees of both companies which led to the collapse of the two companies (Arel et al., 2005). Moreover, this long relationship may lead to such close identification of the auditing firm with the interests of its customer's management that truly independent action by the auditing firm becomes difficult and hence independence is compromised (Geiger \& Raghunandan, 2002). Similarly, Chi et al., (2009) argue that mandatory audit rotation reinforces auditor independence in appearance. In contrast, other researchers argue that long auditor rotation has a positive impact on audit quality (George, 2004; Ghosh\& Moon's, 2005; Arel et al., 2005; Knechel\&Vanstraelen, 2007; Jackson et al., 2008). Jackson et al., (2008) argue that the length of audit rotation leads actually to strengthens audit quality and reduce the costs. Furthermore, imposing mandatory limits on the duration of the auditor-customer relationship might impose unintended costs on capital markets (Ghosh \& Moon's, 2005). George (2004) argues that a new engagement involves higher risk as auditors lack the customer-specific knowledge essential to effectively conduct auditing and this knowledge of the customer and its business environment is something obtained by experience with the client over time. Audit failures are generally higher in the first years of the auditor-customer relationship as the new auditor becomes familiar with the customer's operations (Arel et al., 2005).

Therefore, it cannot use the mandatory rotation of auditors as a surrogate for audit quality alone in isolation from all other factors. It is clear that policy of mandatory rotation of auditors as a way to counter the perception that long-term relationships between auditors and their clients impair auditor independence. Many researchers 
too consider tenure of audit firms as an element of independence external auditing (Act SOX, 2002; George, 2004; Abu Bakar et al., 2005; Jackson et al., 2008; Abu Bakar \& Ahmad, 2009).

\subsection{Provision of Non-Audit Services (NAS)}

The Enron case has highlighted that the provision of non-audit services (NAS) can endanger auditor independence (Quick \& Rasmussen, 2005). The professional bodies, academics, professionals and researchers have focused on non-audit services, such as; Defond et al., 2002; Rasmussen, 2005; Felix et al., 2005. The companies have increasingly turned to providing customers with far more profitable non audit services, and especially for the big firms, which some estimate now receive $30 \%$ to $40 \%$ of their revenues from non-audit services (Walker, 1999). Overall, many researchers argue that NAS weaken objectivity, as well as independence, whereas others found that there exists no association between NAS and audit quality (Frankel et al., 2002; Kilgore, 2007; Salehi, 2009). Defond et al., (2002) have observed that, researchers are concerned about two effects of NAS. First is a fear that the NAS fees make auditors financially dependent on their customers, and hence less willing to stand up to management pressure for fear of losing their business. Second is that the consulting nature of many NAS puts auditors in managerial roles, potentially threatening their independence about the transactions they audit. Felix et al., (2005) argue that when auditors provide NAS to audit clients, the level of client pressure increases and they become less concerned with the internal audits quality, and that this situation influences the decisions made in the gathering of audit evidence, and the audit process. The SOX Act of 2002 implemented a ban on NAS including: 1) financial information systems design, and implementation, and bookkeeping; 2) appraisal services and internal audit services; 3) management functions and human resources; and 4) broker-dealer services and legal services. According to this perspective, Markelevich et al., (2005) noted that the rendering of NAS leads to; impairment of independence, lower quality audits, and increases in the likelihood of GAAP violations.

In contrast, many studies find no association between NAS and audit quality. Frankel et al., (2002) argues that, several writers have re-examined the negative effects of NAS on audit quality, and they found in their study that NAS has no effect on auditors' independence. According to Arruanda (1999), the provision of NAS reduces total costs, increases technical competence and motivates more intense competition. Arruanda adds that it does not necessarily damage auditor independence or the quality of NAS. Reynolds et al. (2004) provide evidence that there is no association between NAS and discretionary accruals and conclude that little evidence exists supporting the negative effects of NAS on auditor's independence and objectivity. Lennox (1999) finds that NAS increases auditors' knowledge on clients as well as the probability of discovering problems and mistakes.

Kilgore (2007) has stated that while the empirical evidence is unclear, what is clear is that corporate regulators worldwide, and many other stakeholders, consider NAS a threat to independence. As summarized by Schneider et al. (2006), prior studies reached mixed results but most generally the results indicate that NAS can negatively affect auditor independence perception. This view has been reinforced recently by spectacular corporate collapses and apparent audit failures associated with them. This is in line with the suggestions in prior literature advocating the use of the elements of independence (e.g., Abu Bakar et al., 2005; Chen et al., 2005; and Abu Bakar \& Ahmad, 2009).

\subsection{Industry Experience}

According to Meyer (2009), industry specialist auditors have developed industry specific knowledge that may enable them to provide higher audit quality than non-specialist auditors. Reichelt\& Wang (2010) conclude that audits by industry specialists improve the quality of corporate earnings, and are more conservative in their audit opinions. Moroney \& Carey's (2011) research findings indicates that industry experience has a more significant impact on the quality of auditor judgment than task-based experience and performance gains through industry experience occur quickly and then level out. One of the key elements found by Schauer (2002) that affects the level of audit quality provided by an auditor is the auditor's industry knowledge. Cadman \& Stein (2007) claim that the demand for higher quality audits may lead specialist audit firms to provide higher quality audits, at increased fees. In addition, in contrast, some specialist auditors may provide a non-differentiated product at discounted fees or provide higher audit quality. In this context, Hogan \& Jeter (1998) provides evidence of the link between industry experience and audit quality arguing that firms with industry experience have financial savings and gains in audit quality.

The above findings show thatindustry experience enhances the performance of external audit function that will lead to better audit quality. As mentioned, it cannot measure audit quality alone in isolation from all other factors. So, industry experience is an important factor of audit quality measurement. 


\subsection{Peer Review}

Albring et al., (2007) argue that "peer review is a quality control mechanism designed to ensure that all audit process adhere to minimum quality standards." Peer review has for many years been an integral part of the AICPA's program for enhancing quality in the auditing profession (Casterella et al., 2009). The laws by New York Governor David Paterson, lead to major changes in the way auditing firms undergo peer review, and joined 44 other states and jurisdictions where peer review is mandatory (Grumet, 2009). The findings point to the fact that peer-review outcomes are associated with actual audit quality and useful in predicting audit failure (Casterella et al., 2009). Hillary \& Lennox (2005) test the opinions issued by the peer reviewers' provision of reliable and credible information to customers about audit quality firm. Hillary \& Lennox observe that audit companies gained customers after receiving clean opinions from their reviewers and lost customers after receiving modified or adverse opinions. This provides evidence of peer review opinions provision of customer information regarding the quality differences between audit companies.

Through the discussion of the previous studies that used indirect approach as an alternative to measure audit quality it isevident that one variable alone cannot measure audit quality. There are some opinions that do not support the use of surrogates to measure audit quality.One variable alonecannot examine the audit quality factors in isolation of all other factors (Carcello et al., 1992; DeFond, 1992). Thus, the use of the indirect approach to assess audit quality by checking the attributes or factors perceived to be associated with audit quality by parties involved in, or affected by, the audit process and audit reports are considered best suited to measuring audit quality. A set of variables that must be considered in future research, in addition to the above factors when measuring audit quality include; independence, education and training, experience, professional conduct, planning, supervision, specialization in the industry, professional body, laws and regulations, and recognized standards. These variables have an impact on audit quality, and hence should be not neglected in future.

\section{Conclusion}

This paper summarizes the previous studies that dealt with surrogates to audit quality. Dealt with the impact of audit firm size, litigation, auditor tenure, provision of non-audit services, industry experience, and peer review on audit quality. Favorable opinions and opposition to the use of the indirect approach in measuring audit quality as surrogates or proxies for qualityare discussed. Based on the foregoing discussion, there are discrepancies between views of the researchers on the factors that may influence the improvement of audit quality. Generally, the use of the indirect approach in assessing audit quality can be considered as the best approachto measuring audit quality.

\section{References}

Abdel Ghany, K. (2012). Do Government Audits Need Engagement Quality Reviews? The Journal of Government Financial Management, 61(1), 48-4.

Abu Bakar, N. B., Abdul Rahman, A. R., \& Abdul Rashid, H. M. (2005). Factors Influencing Auditor Independence: Malaysian Loan Officers' Perceptions. Managerial Auditing Journal, Bradford, 20(9), 804-822. http://dx.doi.org/10.1108/02686900510619665

Abu Bakar, N. B., \& Ahmad, M. (2009). Auditor Independence: Malaysian Accountants' Perceptions. International Journal of Business and Management, 4(12), 129-141.

Albring, S. M., Elder, R. J., \& Zhou, J. (2007). IPO Underpricing and Audit Quality Differentiation Within Non-Big 5 Firms. International Journal of Auditing, 11(2), 115-131. http://dx.doi.org/10.1111/j.1099-1123.2007.00360.x

Arel, B., Brody, R., \& Pany, K. (2005). Audit Firm Rotation and Audit Quality. The CPA Journal, 75(1), 36-39.

Arruñada, B. (1999). The Economics of Audit Quality: Private Incentives and the Regulation of Audit and Nonaudit Services (1st ed.). Publisher: Kluwer Academic Publishers, Springer-Verlag New York, LLC.

Basel Committee. (2008). External Audit Quality and Banking Supervision.Bank for International Settlements, Basel Committee on Banking Supervision, CH-4002 Basel, Switzerland. Retrieved from http://www.bis.org/publ/bcbs146.pdf

Broberg, P. (2007). Regulation in the Name of Audit Quality - How Does it Affect Audit Practice? A Case Study of a Swedish "Big 4" Audit Firm. A Ph.D. Thesis, Department of Business Administration, School of Economics and Management, Lund University.

Cadman, B., \& Stein, M. (2007). Industry Specialization and Auditor Quality in U.S Markets. Working Paper 
Series. Retrieved fromhttp://papers.ssrn.com/sol3/papers.cfm?abstract_id $=722203$

Carcello, J. V., Hermanson, R. H., \& McGrath, N. T. (1992). Audit Quality Attributes: the Perceptions of Audit Partners, Preparers, and Financial Statement Users. Auditing: A Journai of Practice \& Theory, 11(1), 1-15.

Carlin, T. M., Finch, N., \& Laili, N. H. (2009). Questioning the Big 4 Audit Quality Assumption: New Evidence from Malaysia. MGSM Working Paper No. 2008-9 MGSM, the Icfai University Press.

Casterella, J. R., Jensen, K. L., \& Knechel, W. R. (2009). Is Self-Regulated Peer Review Effective at Signaling Audit Quality? The Accounting Review, American Accounting Association, 84(3), 713-735. http://dx.doi.org/10.2308/accr.2009.84.3.713

Chi, W., Huang, H., Liao, Y., \& Xie, H. (2009). Mandatory Audit-Partner Rotation, Audit Quality and Market Perception: Evidence from Taiwan. Contemporary Accounting Research, 26(2), 359-391.

Choi, J. H., Kim, F., Kim, J. B., \& Zang, Y. (2010). Audit Office Size, Audit Quality and Audit Pricing. Journal of Practice \& Theory, 29(1), 73-97. http://dx.doi.org/10.2308/aud.2010.29.1.73

Colbert, G., \& Murray, D. (1999). State Accountancy Regulations, Audit Firm Size, and Auditor Quality: An Empirical Investigation. Journal of Regulatory Economics, 16(3), 267-285.

Davidson, R. A. (1993). A Note on the Association between Audit Firm Size and Audit Quality. Contemporary Accounting Research, 9(2), 479-488.

DeAngelo, L. E. (1981). Auditor Size and Audit Quality. Journal of Accounting and Economics, 3, 183-199. http://dx.doi.org/10.1016/0165-4101(81)90002-1

DeFond, M. L. (1992). The Association between Changes in Client Firm Agency Costs and Auditor Switching. Auditing: A Journal of Practice \& Theory, 11(1), 16-31.

DeFond, M. L., Raghunandan, K., \& Subramanyam, K. R. (2002). Do Non-Audit Service Fees Impair Auditor Independence? Evidence from Going Concern Audit Opinions. Journal of Accounting Research, 40(4), 1247-1274. http://dx.doi.org/10.1111/1475-679X.00088

Ehlen, C. R., \& Welker, R. B. (1996). Procedural Fairness in the Peer and Quality Review Programs. Auditing: A Journal of Practice \& Theory, 15(1), 38-52.

Epstein, M. J., \& Geiger, M. A. (1994). Investor Views of Audit Assurance: Recent Evidence of the Expectation Gap. Journal of Accountancy, 177(1), 60-66.

Felix, W., Gramling, A., \& Maletta, M. (2005). The Influence of Non-Audit Service Revenues and Client Pressure on External Auditors' Decisions to Rely on Internal Audit. Contemporary Accounting Research, 22(1), 31-53. http://dx.doi.org/10.1506/JN7X-B51L-V45W-4U7R

Francis, J. R. (2004). What Do We Know About Audit Quality? The British Accounting Review, 36, 345-368. http://dx.doi.org/10.1016/j.bar.2004.09.003

Francis, J. R., Maydew, E. L., \& Sparks, H. C. (1999). The Role of Big 6 Auditors in the Credible Reporting of Accruals. Auditing, 18(2), 17-18.

Frankel, R. M., Johnson, M. F., \& Nelson, K. K. (2002). The Relation between Auditors' Fees for Non-Audit Services and Earnings Quality. The Accounting Review, 77, 71-105.

Geiger, M., \& Raghunandan, K. (2002). Auditor Tenure and Audit Reporting Failures. Auditing: A Journal of Practice and Theory, 21(1), 67-78. http://dx.doi.org/10.2308/aud.2002.21.1.67

George, N. (2004). Auditor Rotation and the Quality of Audits. The CPA Journal, 74(12), 22-26.

Ghosh, A., \& Moon, D. (2005). Auditor Tenure and Perceptions of Audit Quality. The Accounting Review, 80(2), 585-612. http://dx.doi.org/10.2308/accr.2005.80.2.585

Grumet, L. (2009). New Law Raises the Bar for Audit Quality. The CPA Journal, 79(4).

Hillary, G., \& Lennox, C. (2005). The Credibility of Self-regulation: Evidence from the Accounting Profession's Peer Review Program. Journal of Accounting \& Economics, 40(1-3), 211-229. http://dx.doi.org/10.1016/j.jacceco.2005.03.002

Hogan, C. E., \& Jeter, D. C. (1998). Industry Specialisation by Auditors. Auditing: A Journal of Practice and Theory, 18, 1-17.

IFAC. (2007). Audit Quality and International Standards on Auditing. New York. Retrieved from http://www.ifac.org 
Imhoff, E. A. (1988). A Comparison of Analysts' Accounting Quality Judgements among CPA Firms' Clients. Auditing: A Journal of Practice \& Theory, 7, 182-91.

Iskandar, T. M., Rahmat, M. M., \& Ismail, H. (2010). The Relationship between Audit Client Satisfaction and Audit Quality Attributes: Case of Malaysian Listed Companies. International Journal of Economics and Management, 4(1), 155-180.

Jackson, A. B, Moldrich, M \& Roebuck, P. (2008). Mandatory Audit Firm Rotation and Audit Quality. Managerial Auditing Journal, 23(5), 420-437. http://dx.doi.org/10.1108/02686900810875271

Kilgore, A. (2007). Corporate Governance, Professional Regulation and Audits Quality. Malaysian Accounting Review, 6(1), 65-84.

Knechel, W. R., \& Vanstraelen, A. (2007). The Relationship between Auditor Tenure and Audit Quality Implied by Going Concern Opinions. Auditing: A Journal of Practice \& Theory, 26(1), 113-131. http://dx.doi.org/10.2308/aud.2007.26.1.113

Lam, S., \& Chang, S. (1994). Auditor Service Quality and Auditor Size: Evidence from Initial Public Offerings in Singapore. Journal of International Accounting Auditing and Taxation, 3(1), 103-114. http://dx.doi.org/10.1016/1061-9518(94)90009-4

Lennox, C. S. (1999). Audit Quality and Auditor Size: An Evaluation of Reputation and Deep Pockets Hypotheses. Journal of Business Finance and Accounting, 26(7\&8), 779-805.

Markelevich, A., Hoitash, R., \& Barragato, C. A. (2005). Auditor Fees, Abnormal Fees and Audit Quality Before and After the Sarbanes-Oxley Act. Working Paper, Suffolk University, Electronic copy. Retrieved from http://papers.ssrn.com/sol3/papers.cfm?abstract_id $=646681$

Meyer, K. (2009). Industry Specialization and Discretionary Accruals for Big 4 and Non-Big 4 Auditors. A Ph.D. Thesis, Department of Accounting, The Florida State University.

Moroney, R., \& Carey, P. (2011). Industry Versus Task-Based Experience and Auditor Performance. Auditing: A Journal of Practice \& Theory, 30(2), 1-18. http://dx.doi.org/10.2308/ajpt-10060

Palmrose, Z. V. (1988). An Analysis of Auditor Litigation and Audit Service Quality. The Accounting Review, 63(1), 55-73.

Quick, R., \& Rasmussen, W. (2005). The Impact of MAS on Perceived Auditor Independence-Some Evidence from Denmark. Accounting Forum, 29(2), 137-168. http://dx.doi.org/10.1016/j.accfor.2004.09.001

Reichelt, K. J., \& Wang, D. (2010). National and Office-Specific Measures of Auditor Industry Expertise and Effects on Audit Quality. Journal of Accounting Research, 48(3), 647-686.

Reisch, J. T. (2000). Ideas for Future Research on Audit Quality. The Audit Report, 24(1).

Reynolds, J. K., Deis Jr., D. R., \& Francis, J. R. (2004). Professional Service Fees and Auditor objectivity. Auditing: A Journal of Practice \& Theory, 23(1), 29-52.http://dx.doi.org/10.2308/aud.2004.23.1.29

Salehi, M. (2009). Non-Audit Service and Audit Independence: Evidences from Iran. International Journal of Business and Management, 4(2), 142-152.

Schauer, P. C. (2002). The Effects of Industry Specialization on Audit Quality: An Examination Using Bid-Ask Spreads. Journal of Accounting \& Finance Research, 10(1), 76-108.

Schneider, A., Church, B. K., \& Ely, K. M. (2006). Non-Audit Services and Auditor Independence: A Review of the Literature. Journal of Accounting Literature, 25, 169-211.

Schwartz, R. (1997). Legal regimes, audit quality and investment. The Accounting Review, 72(3), 385-406.

Sori, Z. M., Mohamad, S., \& Karbhari, Y. (2006). Auditor Reputation and Auditor Independence: Evidence from an Emerging Market. Working Paper Series, Centre of Excellence for Applied Financial and Accounting Studies and Cardiff Business School, University Putra Malaysia.

Sutton, S. G. (1993). Toward an Understanding of the Factors Affecting the Quality of the Audit Process. Decision Sciences, 24, 88-105.

Tate, S. L. (2002). Differences in Financial Statement and Compliance Audit Assessments between Big 5 and Non-Big 5 Auditors. Working Paper, the International Symposium on Audit Research, Michigan State University. Retrieved from http://unhinfo.unh.edu/acfi/tate-1.pdf

Walker, R. H. (1999). Auditors, Accountant independence, SEC accounting policies, Perceptions, Materiality. 
The CPA Journal, 69(5), 44-49.

Watkins, A. L., Hillison, W., \& Morecroft, S. E. (2004). Audit Quality: A Synthesis of Theory and Empirical Evidence. Journal of Accounting Literature Gainesville, 23, 153-193.

Willekens, M., \& Simunic, D. (2007). Precision in Auditing Standards: Effects on Auditor and Director Liability and the Supply and Demand for Audit Services. Accounting and Business Research, 37(3), 217-232.

Wyer, J. C., White, G. T., \& Janson, E. C. (1988). Audits of Public Companies by Smaller CPA Firms: Clients Reports and Quality. Auditing: A Journal of Practice \& Theory, 7(2), 164-173.

\section{Copyrights}

Copyright for this article is retained by the author(s), with first publication rights granted to the journal.

This is an open-access article distributed under the terms and conditions of the Creative Commons Attribution license (http://creativecommons.org/licenses/by/3.0/). 